\title{
RARE AND PROTECTED SPECIES IN THE DRAINAGE DITCHES AND ADJACENT PHYTOCOENOSES IN THE POLESIE NATIONAL PARK
}

\author{
Barbara Banach \\ Department of General Ecology, University of Life Sciences, Akademicka 15, 20-950 Lublin, Poland \\ e-mail:barbara.banach@up.lublin.pl
}

Received: 29.09 .2008

S u m m a r y

This paper presents the results of a floristic study conducted in the years 2003 - 2005 within the area of the Polesie National Park and its protective zone. Floristic inventories were carried out in twelve 100-metre-long sections of the drainage ditches and adjacent phytocoenoses and based on them office analyses of the flora were performed. The aim of the study was to determine the share of species with special natural values in the drainage ditches, taking into account the occurrence of legally protected, rare and endangered taxa at the regional level, in Poland and in Europe. The share of these species was also compared with the richness of special concern plants noted in the phytocoenoses adjacent to the investigated ditches. Based on the floristic composition, an analysis was made of the occurrence of taxa whose number of stands shows a declining trend compared to the Polish flora. The number of vascular plant species found in the ditches and in their vicinity was similar, but the low values of the similarity index suggest differences in the species composition of these habitats, which results in greater species diversity. The presence of special concern plants in the drainage ditches suggests that they are valuable habitats for the Polesie National Park. They create niches for rare, protected and endangered species.

Key words: protected species, vascular flora, drainage ditches, Polesie National Park, floristic diversity

\section{INTRODUCTION}

Biological diversity, in particular over the recent time, has been severely threatened by human activity. It is estimated that every day about 70 organism species disappear irretrievably from our planet. If this number is converted into months or years, it will show a frightening result. One of the reasons for the dying-out of species is wetland drainage (To m i ało j ć, 1995). In Poland most wetlands are subjected to anthropopressure, mainly involving their drainage (J a s n o w s k i, 1972). Such activities have contributed to a reduction in species diversity of plants and animals characteristic of such areas.

A part of drainage ditches, created by human activity, is located within the area of the Polesie National Park, thus, within a protected area. These astatic, sometimes densely overgrown, since devoid of maintenance for a long time, small waterlogged habitats are niches where the flora driven out of drained areas has found a place for living. The channels of these ditches should be treated not only as structures used for water discharge, but also as a place of living for many plant and animal species. They are also a valuable element distinguishing this landscape (J aw orowski et al. 1996).

The drainage infrastructure cutting across the Polesie National Park area is a particularly interesting object of scientific research due to the absence of thorough studies on flora species diversity of these anthropogenic habitats. The compensation and systematization of data on plant species diversity and its conditions, in anthropogenic habitats located within the boundaries of a protected area, is extremely important due to an insufficient level of their knowledge. Therefore, analysis of the floristic composition and verification of habitat conditions in the drainage ditches located within the Park area and its buffer zone are of key significance. The knowledge of these issues is necessary for the management of a legally protected area and for the development of active conservation plans. The knowledge of the richness of special concern species in these ecosystems is of essential importance, due to risks arising from changes taking place in the natural environment.

The aim of the present study was to determine the share of species with special natural values in the drainage ditches, taking into account the occurrence of legally protected, rare and endangered taxa on the regional level, in Poland and in Europe. 


\section{MATERIALS AND METHODS}

The field study was carried out in the growing seasons in the years 2003-2006, within the area of the Polesie National Park and its protection zone. In 2003 the flora was investigated in summer and autumn, whereas in the other years also in spring. The drainage ditches were the object of the study.

At the first stage of the study, 12 study objects were selected - the drainage ditches. In order to cover in the study the widest possible range, ditches cutting across different phytocoenoses characteristic of the Park were selected, notably forest, meadow, field and bog phytocoenoses. Next, study areas were selected, which were 100-metre-long sections of the drainage ditches. The floristic study covered both the bottom and slopes of the ditches as well as the adjacent ground. Floristic inventories were conducted in the study areas and in the adjacent phytocoenoses.

The location of the selected study sites was determined using the Global Positioning System (GPS). Each site and the study area located at the respective site, designated by an abbreviation "pb", were assigned a number - Latin numerals (Fig. 1), and the adjacent habitats were additionally designated by an abbreviation "fs":

I. study site within the area of the "Bagno Orłowskie" complex in the Polesie National Park (PNP) (study area no. I, adjacent phytocoenosis no. Ifs);

II. study site near Lake Długie in PNP - the feeding canal Bogdanka - Wola Wereszczyńska (study area no. II, adjacent phytocoenosis no. IIfs);

III. study site in the village of Jamniki near Lake Moszne in PNP (study area no. III, adjacent phytocoenosis no. IIIfs);

IV. study site near Lake Moszne situated along an educational trail - PNP area (study area no. IV, adjacent phytocoenosis no. IVfs);

V. study site next to the "Spławy" educational trail leading to Lake Łukie in PNP (study area no. V, adjacent phytocoenosis no. Vfs);

VI. study site near the village of Sęków in the "Bagno Bubnów" peat bog complex in PNP (study area no. VI, adjacent phytocoenosis no. VIfs);

VII. study site close to the village of Załucze Nowe in the PNP protection zone - the feeding canal Bogdanka - Wola Wereszczyńska (study area no. VII, adjacent phytocoenosis no. VIIfs);

VIII. study site in the vicinity of Ciek Zienkowski (Zienkowski Watercourse) near the village of Zbójno in PNP (study area no. VIII, adjacent phytocoenosis no. VIIIfs);

IX. study site near Lake Karaśne in the vicinity of the village of Łomnica in PNP (study area no. IX, adjacent phytocoenosis no. IXfs);
X. study site in the "Pociagi" (Trains) meadows near the village of Lipniak in PNP (study area no. $\mathrm{X}$, adjacent phytocoenosis no. Xfs);

XI. study site within the "Perehod" pond complex in PNP (study area no. XI, adjacent phytocoenosis no. XIfs);

XII. study site near Lake Wytyckie in Brzeziny Forest in PNP (study area no. XII, adjacent phytocoenosis no. XIIfs).

Species nomenclature follows $\mathrm{Mirek}$ et al. (2002).

Based on the conducted floristic inventories, a list of all vascular plant species of the studied drainage ditches and a list of the flora of all the adjacent phytocoenoses were made. These inventories were made in tables in which the corresponding status of the respective taxon was assigned to each species in relation to the following ten documents and studies on the conservation of regional, Polish and European flora:

$\checkmark \quad$ The red list of endangered vascular plants in Poland (Z a r z y c ki and S z e ląg, 1992),

$\checkmark$ Endangered species of bog flora ( $\mathrm{J}$ a s n ow s ka and J a s n o w s k i, 1977),

$\checkmark$ Rare and endangered species of the Polish flora (J a s i ew i c z, 1981),

$\checkmark \quad$ Strictly and partially protected species (under the Regulation of the Minister of Environment of 9 July 2004, Dz. U. (Journal of Laws) No. 168, item 1764),

$\checkmark$ The Red Book of Ukraine (Červona kniga Ukraïni, 1996),

$\checkmark$ The Red Book of Belarus (Krasnaâ kniga Respubliki Belru", 2006),

$\checkmark$ Critically endangered and endangered vascular plant species of Wyżyna Lubelska, Roztocze, Wołyń Zachodni and Polesie Lubelskie (Kucharczyk and Wójcik, 1995),

$\checkmark \quad$ List of more rare plants of the Lublin region, Parts I - VII (F i j a ł k o w s k i , 1954; 1958; 1959; 1960; 1962; 1963; 1964),

$\checkmark$ The degree of endangerment ( $\mathrm{Zarzycki}$ et al. 2002),

$\checkmark$ Plant species requiring protection in the form of designation of Natura 2000 sites (under the Regulation of the Minister of Environment of 16 May 2005, Dz. U. (Journal of Laws) No. 94).

The flora of the drainage ditches and adjacent phytocoenoses was analysed in terms of the occurrence of protected plant species or those included in special concern species, also taking into account the following documents and studies:

$\checkmark$ Vascular plant species covered by the Habitats Directive (Council Directive 92/43/EEC 1992),

$\checkmark \quad$ The Polish Red Book of Plants (K a ź m i e r c z a k ow a and Zarzy cki, 2001), 
Vascular plant species covered by the Bern Convention (the Convention on the Conservation of European Wildlife and Natural Habitats, 1979).

Due to the fact that no species included in the abovementioned studies and documents occurred in the investigated communities, they are not included in the tables.

Jaccard's formula was used to calculate the similarity index between the species composition of the study areas and adjacent phytocoenoses (W y s o cki and Sikorski, 2002).

\section{RESULTS}

In the flora of the drainage ditches in the Polesie National Park (PNP) and their adjacent phytocoenoses, the presence of 30 taxa was noted which are mentioned in the lists of the so-called "special concern" species. 222 vascular flora species, including 18 rare or protected species, were noted in the drainage ditches, whereas in the adjacent phytocoenoses 182 vascular flora species, including 16 covered by different forms of protection (Tab. 1).

From "The red list of endangered vascular plants in Poland" (Z a r zy cki and S ze ląg, 1992), one species was noted in the PNP ditches, notably Epipactis palustris at site no. II on Lake Długie. In the adjacent phytocoenoses, three species were found from the abovementioned list. These were the following: Carex buxbaumii and Lathyrus palustris at site no. VIfs on the "Bagno Bubnów" peat bog complex and Dryopteris cristata at sites no. IXfs near Lake Karaśne and XIIfs in Brzeziny Forest near Lake Wytyckie.

Since the aquatic-bog environment is predominant in the Polesie National Park, the flora of the investigated sites was analysed based on the publication "Endangered species of bog flora" (Jas nowska and Jas now ski, 1977). 11 taxa were found from this list at all the studied sites, seven species in both the drainage ditches and adjacent phytocoenoses.

At all the studied sites, three species were found from "Rare and endangered species of the Polish flora" (J a s i ew ic z, 1981). One of them (Ceratophyllum demersum) occurred in the drainage ditch located in the "Perehod" pond complex at study site no. XI, the other two in the adjacent phytocoenoses IIfs (Crataegus laevigata), IXfs and XIIfs (Dryopteris cristata).

In accordance with the Regulation of the Minister of Environment of 9 July 2004 on protected wild plants (Dz. U. (Journal of Laws) of 28 July 2004), nine strictly or partially protected taxa were noted in the drainage ditches in the Polesie National Park. Eight of them were totally protected: Agrimonia pilosa, Batrachium aquatile, Centaurium erythraea, Epipactis palustris, Nasturtium officinale, Utricularia interme- dia, Utricularia vulgaris and Veratrum lobelianum, whereas one species was partially protected - Frangula alnus (Tab. 1; Tab. 2).

In the adjacent phytocoenoses, strictly protected species occurred less numerously and these were the following: Aquilegia vulgaris, Cladium mariscus, Melittis melissophylum, and partially protected species included the following: Frangula alnus, Helichrysum arenarium, Menyanthes trifoliata and Viburnum opulus.

The Polesie National Park is a part of the West Polesie Biosphere Reserve established by three states: Poland, Ukraine and Belarus. Due to this fact, the flora of the drainage ditches and adjacent phytocoenoses was compared to the list of plants included in the Red Book of Ukraine (Červona kniga Ukraïni, 1996) and in the Red Book of Belarus (Krasnaâ kniga Respubliki Belru", 2006). According to the Ukrainian list, at the investigated sites in the Polesie National Park, the occurrence of the following species was found: Epipactis palustris in study area no. II as well as Carex buxbaumii and Cladium mariscus in adjacent phytocoenosis no. VIfs. The Red Book of Belarus (Krasnaâ kniga Respubliki Belru", 2006) mentions the same species from the Ukrainian Book which occurred in the adjacent phytocoenoses and additionally the species Melittis melissophylum which was noted at study site no. IIfs in the vicinity of Lake Długie in PNP.

Studies on regional flora were also taken into account. Three species were found at the studied sites from the list of species included in the publication "Critically endangered and endangered vascular plant species of Wyżyna Lubelska, Roztocze, Wołyń Zachodni and Polesie Lubelskie" (K u charc zyk and W ó j cik, 1995) - Epipactis palustris in study area no. II near Lake Długie as well as Carex buxbaumii and Cladium mariscus in adjacent phytocoenosis no. VIfs in the "Bagno Bubnów" bog complex.

A comparison of the flora of the studied sites with the "List of more rare plants of the Lublin region" - Parts I - VII (F i j a łk o w s k i, 1954; 1958; $1959 ; 1960 ; 1962 ; 1963 ; 1964)$ showed nine species from this list. Four of them were noted in the drainage ditches and five in the adjacent phytocoenoses.

Among all the identified species in the study areas and in the adjacent phytocoenoses, eight showed a high level of endangerment ( $\mathrm{Zarzycki}$ et al. 2002). In study areas no. I and XI, the occurrence of Hippuris vulgaris was found; it is a species in danger of extinction according to $\mathrm{Zarzycki}$ et al. (2002). In study area no. II, two species were found with the same degree of endangerment: Sagittaria sagittifolia and Epipactis palustris, and in study area no. VI Utricularia intermedia, as well as Dryopteris cristata in study area no. XII. In the adjacent phytocoenoses, the 
Table 1

List of endangered species of vascular plants in the studied drainage ditches and adjacent phytocoenoses within the area of the Polesie National Park and its protection zone.

\begin{tabular}{|c|c|c|c|c|c|c|c|c|c|c|}
\hline Latin name & 1 & 2 & 3 & 4 & 5 & 6 & 7 & 8 & 9 & 10 \\
\hline \multicolumn{11}{|c|}{ DRAINAGE DITCHES } \\
\hline Agrimonia pilosa Ledeb. & . &. & . & $\mathrm{OC}$ & . & . & . & . & . & $\checkmark$ \\
\hline Batrachium aquatile (L.) Dumort. & . & . & . & $\mathrm{OC}$ & . & . & . & . & . & . \\
\hline Calla palustris $\mathrm{L}$. & . & $\mathrm{R}$ & . & $\cdot$ & . & . & . & . & . & . \\
\hline Carex flava L. & . & $\mathrm{R}$ & . & . & . & . & . & . & . & . \\
\hline Centaurium erythraea Rafn & . & . & . & $\mathrm{OC}$ & . & . & . & . & . & . \\
\hline Ceratophyllum demersum L. s. str. & . & . & $\mathrm{R}$ & . & . & . & . & . & . & . \\
\hline Cirsium rivulare (Jacq.) All. & . & $\mathrm{R}$ & . & . & . & . & . & . & . & . \\
\hline Epipactis palustris (L.) Crantz & $\mathrm{V}$ & $\mathrm{OC}$ & . & $\mathrm{OC}$ & $\checkmark$ & . & . & $\checkmark$ & $\mathrm{V}$ & . \\
\hline Frangula alnus Mill. & . & . & . & Ocz & . & . & . & . & . & . \\
\hline Hippuris vulgaris $\mathrm{L}$. & . & . & . & . & . & . & . & $\checkmark$ & $\mathrm{V}$ & . \\
\hline Hottonia palustris $\mathrm{L}$. & . & $\mathrm{R}$ & . & . & . & . & . & . & . & . \\
\hline Lemna gibba $\mathrm{L}$. & . & . & . & . & . & . & . & $\checkmark$ & . & . \\
\hline Lysimachia thyrsiflora $\mathrm{L}$. & . & $\mathrm{R}$ & . & . & . & . & . & . & . & . \\
\hline Nasturtium officinale R. Br. & . & . & . & $\mathrm{OC}$ & . & . & . & . & . & . \\
\hline Sagittaria sagittifolia L. & . & . & . & $\cdot$ & . & . & . & . & $\mathrm{V}$ & . \\
\hline Utricularia intermedia Hayne & . & $\mathrm{V}$ & . & $\mathrm{OC}$ & . & . & . & $\checkmark$ & $\mathrm{V}$ & . \\
\hline Utricularia vulgaris L. & . & . & . & $\mathrm{OC}$ & . & . & . & . & . & . \\
\hline Veratrum lobelianum Bernh. & . & . & . & $\mathrm{OC}$ & . & . & EN & . & . & . \\
\hline \multicolumn{11}{|c|}{ ADJACENT PHYTOCOENOSES } \\
\hline Aquilegia vulgaris $\mathrm{L}$. & . & . & . & $\mathrm{OC}$ & . & . & . & $\checkmark$ & . & . \\
\hline Bromus arvensis $\mathrm{L}$. & . & . & . & . & . & . & . & . & $\mathrm{E}$ & . \\
\hline Calla palustris $\mathrm{L}$. & . & $\mathrm{R}$ & . & . & . & . & . & . & . & . \\
\hline Carex buxbaumii Wahlenb. & $\mathrm{V}$ & $\mathrm{R}$ & . & . & $\checkmark$ & $\checkmark$ & EN & $\checkmark$ & $\mathrm{E}$ & . \\
\hline Chaerophyllum hirsutum L. & . & . & . & . & . & . & . & $\checkmark$ & . & . \\
\hline Cirsium rivulare (Jacq.) All. & . & $\mathrm{R}$ & . & . & . & . & . & . & . & . \\
\hline Cladium mariscus (L.) Pohl & . & $\mathrm{R}$ & . & $\mathrm{OC}$ & $\checkmark$ & $\checkmark$ & LR & $\checkmark$ & . & . \\
\hline Crataegus laevigata (Poir.) DC. & . & . & $\mathrm{R}$ & . & . & . & . & . & . & . \\
\hline Dryopteris cristata (L.) A. Gray & $\mathrm{V}$ & $\mathrm{R}$ & V & . & . & . & . & $\checkmark$ & $\mathrm{V}$ & . \\
\hline Frangula alnus Mill. & . & . & . & Ocz & . & . & . & . & $\cdot$ & . \\
\hline Helichrysum arenarium (L.) Moench & & . & . & $\mathrm{Ocz}$ & . & . & . & . & . & . \\
\hline Lathyrus palustris L. & $\mathrm{V}$ & $\mathrm{R}$ & . & . & . & . & . & . & $\mathrm{V}$ & . \\
\hline Lysimachia thyrsiflora $\mathrm{L}$. & . & $\mathrm{R}$ & $\cdot$ & . & . & . & . & . & . & . \\
\hline Melittis melissophylum L. & . & . & · & $\mathrm{OC}$ & . & $\checkmark$ & . & . & . & . \\
\hline Menyanthes trifoliata $\mathrm{L}$. & . & . & . & Ocz & . & . & . & . & . & . \\
\hline Viburnum opulus L. & . & . & . & Ocz & . & . & . & . & . & . \\
\hline
\end{tabular}

Explanations:

1 - The red list of endangered vascular plants in Poland (Zarzycki and Szeląg, 1992); V - Vulnarable. Species which will move to the category of species in danger of extinction in the near future if the risk factors continue to operate,

2 - Endangered species of bog flora (Jas now ska and Jasnow ski, 1977); V-severely endangered species, R - endangered species, OC - legally protected species,

3 - Rare and endangered species of the Polish flora (Ja siew icz 1981); V - endangered species in the Polish flora, R - rare species in the Polish flora numbering up to 30-40 stands,

4 - Strictly and partially protected species (under the Regulation of the Minister of Environment of 9 July 2004 Dz. U. (Journal of Laws) No. 168, item 1764); OC - totally protected species, Ocz - partially protected species,

5 - Červona kniga Ukraïni (2006); $\checkmark$ - species mentioned in the publication,

6 - Krasnaâ kniga Respubliki Belru" (1996); $\checkmark$ - species mentioned in the publication,

7 - Critically endangered and endangered vascular plant species of Wyżyna Lubelska, Roztocze, Wołyń Zachodni and Polesie Lubelskie (Kucharczyk and Wójcik, 1995); EN - endangered species, LR - low-risk species,

8 - List of more rare plants of the Lublin region, Parts I - VII (Fijałkowski, 1954; 1958; 1959; 1960; 1962; 1963; 1964); $\checkmark$ - species mentioned in the publication,

9 - Degree of endangerment (Zarzycki et al. 2002); V - endangered species, E - critically endangered species,

10 - Plant species requiring protection in the form of designation of Natura 2000 sites (under the Regulation of the Minister of Environment of 16 May 2005 Dz. U. (Journal of Laws) No. 94; $\checkmark$ - species mentioned in the publication. 
Table 2

The number of rare flora species according to different lists of protected and rare species.

\begin{tabular}{|c|c|c|c|c|c|c|c|c|c|c|c|c|c|c|}
\hline \multirow{4}{*}{$\begin{array}{l}\text { Study site } \\
\text { number }\end{array}$} & $\begin{array}{c}\text { Number of } \\
\text { species }\end{array}$ & 1 & 2 & 3 & 4 & 5 & 6 & 7 & 8 & 9 & 10 & 11 & 12 & 13 \\
\hline & total & 4 & 11 & 3 & 15 & 3 & 3 & 3 & 9 & 8 & 1 & . & . & . \\
\hline & pb & 1 & 7 & 1 & 9 & 1 & . & 1 & 4 & 4 & 1 & . & . & . \\
\hline & fs & 3 & 7 & 2 & 7 & 2 & 3 & 2 & 5 & 4 & . & . & . & . \\
\hline \multirow[t]{2}{*}{ I } & $\mathrm{pb}$ & . & . & . & 3 & . & . & . & 1 & 1 & . & . & . & . \\
\hline & fs & . & 1 & . & . & . & . & . & . & . & . & . & . & . \\
\hline \multirow[t]{2}{*}{ II } & $\mathrm{pb}$ & 1 & 1 & . & 1 & 1 & . & . & 1 & 2 & . & . & . & . \\
\hline & fs & . & . & 1 & 1 & . & 1 & . & . & 1 & . & . & . & . \\
\hline \multirow[t]{2}{*}{ III } & $\mathrm{pb}$ & . & 1 & . & 1 & . & . & . & . & . & . & . & . & . \\
\hline & fs & . & . & . & 1 & . & . & . & . & . & . & . & . & . \\
\hline \multirow[t]{2}{*}{ IV } & $\mathrm{pb}$ & . & 2 & . & . & . & . & . & . & . & . & . & . & . \\
\hline & fs & . & . & . & 1 & . & . & . & . & . & . & . & . & . \\
\hline \multirow[t]{2}{*}{$\mathrm{V}$} & $\mathrm{pb}$ & . & 2 & . & 1 & . & . & . & . & . & . & . & . & . \\
\hline & fs & . & 1 & . & 2 & . & . & . & . & . & . & . & . & . \\
\hline \multirow[t]{2}{*}{ VI } & $\mathrm{pb}$ & . & 1 & . & 2 & . & . & . & 1 & 1 & . & . & . & . \\
\hline & fs & 2 & 3 & . & 1 & 2 & 2 & 2 & 2 & 1 & . & . & . & . \\
\hline \multirow[t]{2}{*}{ VII } & $\mathrm{pb}$ & . & 3 & . & 2 & . & . & 1 & . & . & . & . & . & . \\
\hline & fs & . & 1 & . & . & . & . & . & . & 1 & . & . & . & . \\
\hline \multirow[t]{2}{*}{ VIII } & $\mathrm{pb}$ & . & . & . & 1 & . & . & . & . & . & . & . & . & . \\
\hline & fs & . & . & . & 1 & . & . & . & . & . & . & . & . & . \\
\hline \multirow[t]{2}{*}{ IX } & $\mathrm{pb}$ & . & 3 & . & 1 & . & . & . & . & . & . & . & . & . \\
\hline & fs & 1 & 1 & 1 & 2 & . & . & . & 2 & 1 & . & . & . & . \\
\hline \multirow[t]{2}{*}{$X$} & $\mathrm{pb}$ & . & 2 & . & 2 & . & . & . & 1 & . & . & . & . & . \\
\hline & fs & . & 1 & . & 1 & . & . & . & . & . & . & . & . & . \\
\hline \multirow[t]{2}{*}{ XI } & $\mathrm{pb}$ & . & 2 & 1 & 1 & . & . & . & 1 & 1 & . & . & . & . \\
\hline & fs & . & . & . & 1 & . & . & . & . & . & . & . & . & . \\
\hline \multirow[t]{2}{*}{ XII } & $\mathrm{pb}$ & . & . & . & 1 & . & . & . & . & . & . & . & . & . \\
\hline & fs & 1 & 2 & 1 & 2 & . & . & . & 2 & 1 & . & . & . & . \\
\hline
\end{tabular}

Explanations:

1-10 see Table 1.

11 - Vascular plant species covered by the Habitats Directive (Council Directive 92/43/EEC 1992),

12 - The Polish Red Book of Plants (Kaźmierczakowa and Zarzycki, 2001),

13 - Vascular plant species covered by the Bern Convention (the Convention on the Conservation of European Wildlife and Natural Habitats, 1979). 


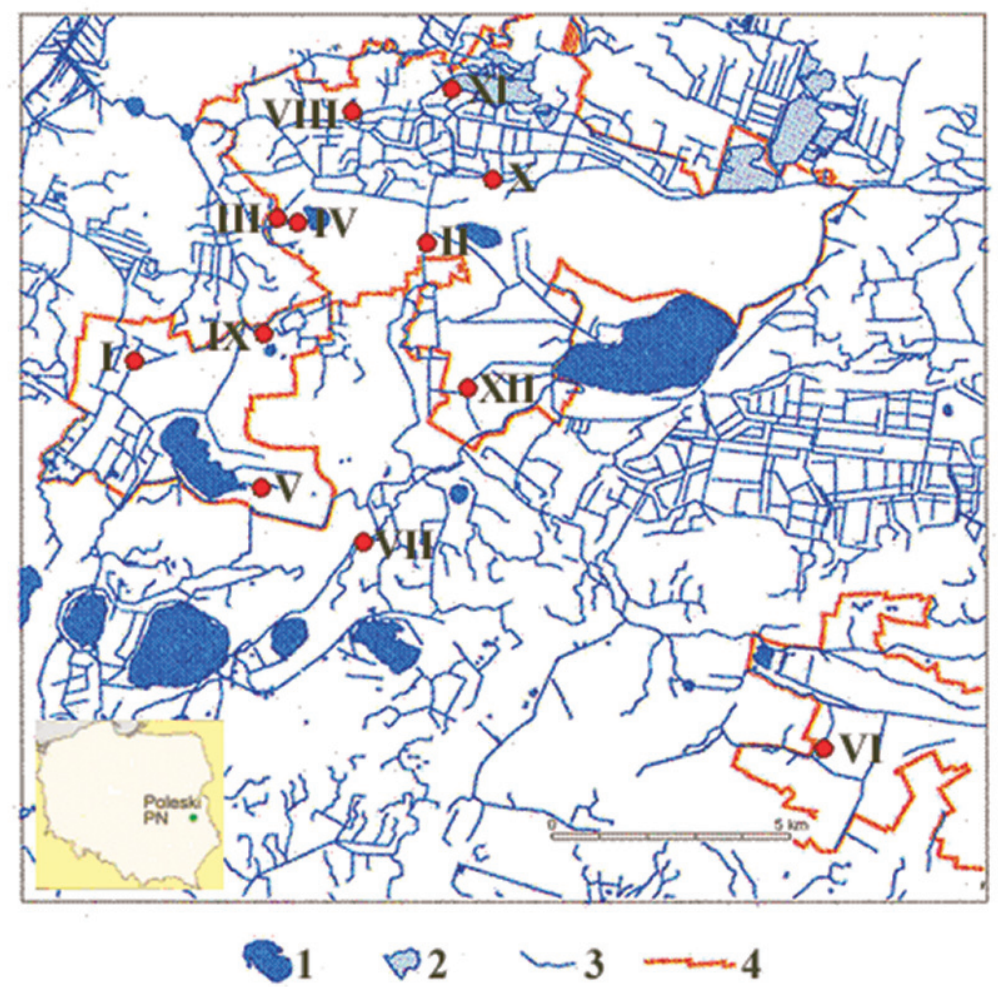

Fig. 1. Distribution of study sites within the area of the Polesie National Park and its protection zone;

1 - lake; 2 - artificial water reservoir; 3 - drainage ditches and other watercourses; 4 -Polesie National Park boundary (Michalczyk et al. 2003; changed).

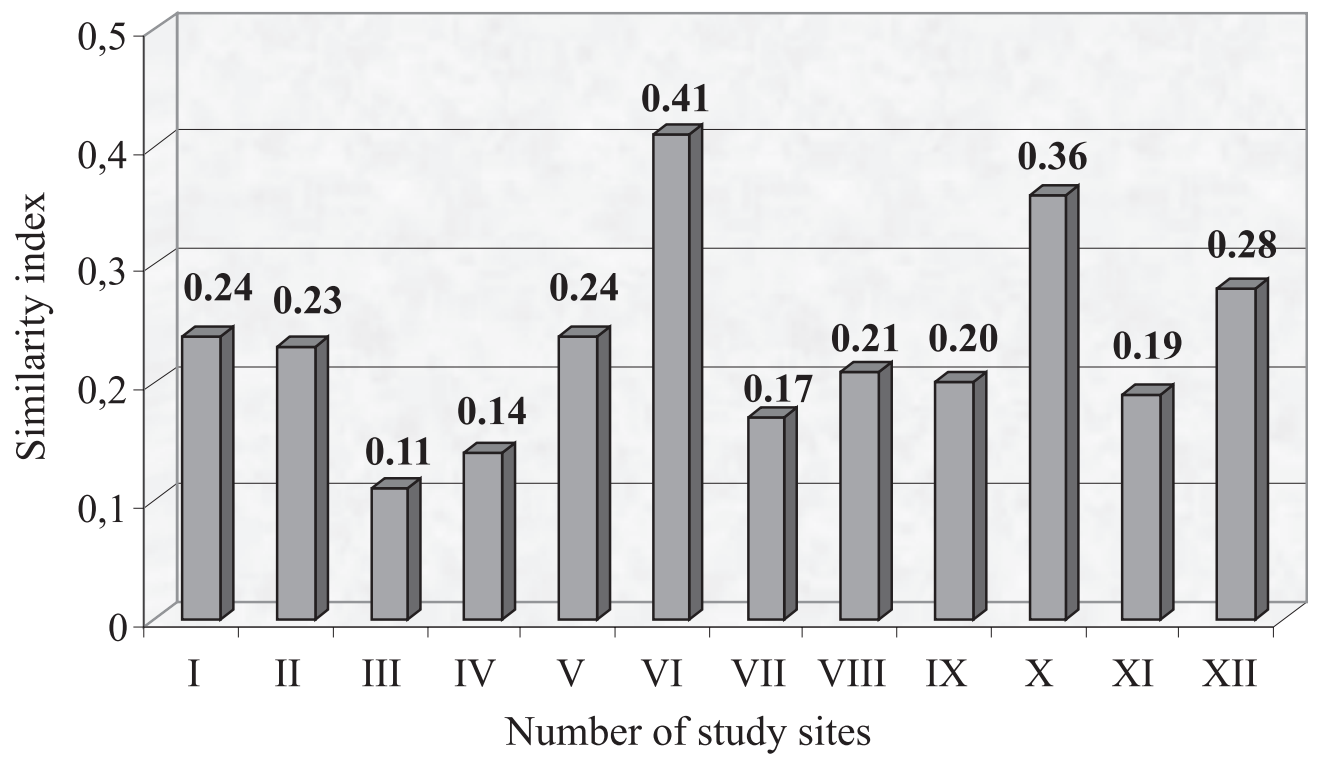

Fig. 2. The level of similarity index between drainage ditches and adjacent phytocoenoses. 
following plant species in danger of extinction were noted: Lathyrus palustris (study site no. VIfs) and Dryopteris cristata (site no. XIIfs) as well as critically endangered species: Carex buxbaumii (site no. VIfs) and Bromus arvensis (site no. VIIfs). No special concern species were noted in the other study areas and in their vicinity.

The flora of the drainage ditches in the PNP and in their adjacent phytocoenoses was compared with a list of plant species requiring protection in the form of designation of Natura 2000 sites (the Regulation of the Minister of Environment of 16 May 2005 Dz. U. (Journal of Laws) No. 94). In the drainage ditch at site no. X, there was noted the taxon Agrimonia pilosa included in the abovementioned list (Tab. 1; Tab. 2).

No species from the list of plants of the investigated drainage ditches and adjacent phytocoenoses in the PNP was found in the other documents and studies such as "Vascular plant species covered by the Habitat Directive" (Council Directive 92/43/EEC 1992), "The Polish Red Book of Plants" (K a ź mi e r c z a k ow a and $\mathrm{Z}$ ar z y ck i, 2001), "Vascular plant species covered by the Bern Convention (the Convention on the Conservation of European Wildlife and Natural Habitats, 1979).

The carrying out of the floristic inventories in the study areas as well as in the adjacent phytocoenoses allowed the species similarity of these habitats to be compared. In spite of the fact that the number of species in the ditches (222 taxa) and in their vicinity (182 taxa) was similar, the similarity index, calculated in accordance with Jaccard's formula, showed that this similarity was low and it ranged from 0.11 at site no. III and 0.14 at site no. IV to 0.41 at site no. VI (a slightly lower value of this index, standing at 0.36 , was noted for site no. X; Fig.1). At the other study sites, the value of this index was within the range of $0.10-0.28$.

\section{DISCUSSION}

The occurrence of protected, rare and endangered species in the studied sites may be a measure of their environmental preciousness.

The analysis of the flora in terms of the degree of endangerment of species or their legal status allowed us to find out whether the habitats of anthropogenic origin, which drainage ditches are, could be considered to be environmentally valuable habitats. It is also an important fact that the investigated sites are located in most cases within a legally protected area - in a national park.

The assessment of the degree of species endangerment was based on indicator values of vascular plants relating to the degree of their endangerment according to Z a r z y k i et al. (2002), on the list of legally protected species specified in the Regulation of the Minister of Environment of 9 July 2004 on protected wild plants (Dz. U. (Journal of Laws) of 28 July 2004) as well as on eleven other studies on rare or endangered flora at the regional, national or European level.

Literature characterising the vascular flora of the Polesie National Park often mentions protected, rare or endangered species occurring in great numbers within its area. Legal protection of species is closely associated with legislative changes. The finding of the occurrence of rare or protected taxa in the anthropogenic habitats may prove that these species find in the drainage ditches suitable living conditions for them. The occurrence of nine totally or partially protected species was found in the drainage ditches in the PNP, and in the adjacent phytocoenoses seven.

Fijałkowski (1971) found the numerous occurrences of rare species in the area of Wytyczno. He stressed at that time the fact that land drainage works would be carried out in this area; therefore, the occurrence of these species would be severely threatened in the future. Among the rare plant species occurring in this area, mentioned by Fijałk owski et al. 1971, the occurrence of only three taxa: Utricularia intermedia, Epipactis palustris and Veratrum lobelianum, was noted in the study areas included in the author's investigations.

In 1996 Sołtys and Różycki reported that 26 endangered vascular plant species, of different legal status, occurred within the PNP area. Only one species, Epipactis palustris, occurred in the study areas from the list presented by the abovementioned authors.

Załuski and Kamińska (1999) noted relict and protected species in the drainage ditches of a bog meadow complex in Koszelewki (Garb Lubawski). The following species were found at the sites investigated by them: Polemonium caeruleum, Viola epipsila and Betula humilis. None of the above-mentioned taxa was found in the studied areas in the PNP, but other endangered and legally protected species occurred in greater numbers in the artificial watercourses than in the adjacent phytocoenoses.

Ludera, describing in 1976 the occurrence of Veratrum lobelianum in Poland, mentioned that it could be encountered only in mountainous areas, whereas Fijałkowski and Topolska (1981) mention the Lublin region, and more specifically Załucze, as one of the place of its occurrence. The study of this paper's author confirmed the occurrence of Veratrum lobelianum in study area no. VII, which was situated near the village of Załucze Nowe, on the slope of the investigated drainage ditch section.

The analysis of the flora of the ditches and adjacent phytocoenoses, as compared to studies on the 
conservation of regional, national and European flora, indicates that rare, endangered or vulnerable taxa were noted more frequently in the adjacent phytocoenoses than in the ditches themselves. However, the number of these taxa was similar. The presence of special concern species in these ditches indicates that the drainage ditches are habitats creating niches for protected, rare and endangered species.

The value of the similarity index may be within the range from 0 to 1 , where 0 means the lack of similarity between the phytocoenoses, whereas 1 means one hundred percent similarity of the species composition.

\section{CONCLUSIONS}

1. The presence of special concern species in the drainage ditches indicates that they are valuable habitats for the PNP, since they create niches for rare, protected and endangered species.

2. The drainage ditches, being artificial watercourses, are enclaves of wetland habitats and perform the role of refuges for natural flora originating from habitats subjected to anthropopressure.

3. The number of species in the ditches and in their vicinity was similar, but the low values of the similarity index suggest differences in the species composition of these habitats, which results in greater species diversity.

\section{REFERENCES}

The Council Directive 92/43/EEC of 21 May 1992 on the Conservation of Natural Habitats and of Wild Flora and Fauna.

Fijałkowski D. 1954. Wykaz rzadszych roślin Lubelszczyzny. / List of more rare species of the Lublin region. Fragm. Florist. Geobot. Ann. I, Pars 2: 81-93.

Fijałkowski D. 1958. Wykaz rzadszych roślin Lubelszczyzny. Część II. / List of more rare species of the Lublin region. Part II. Fragm. Florist. Geobot. Ann. III, Pars 2: 3-18.

Fijałkowski D. 1959. Wykaz rzadszych roślin Lubelszczyzny. Część III. / List of more rare species of the Lublin region. Part III. Fragm. Florist. Geobot. Ann. V, Pars 1: 11-35.

Fijałkowski D. 1960. Wykaz rzadszych roślin Lubelszczyzny. Część IV. / List of more rare species of the Lublin region. Part IV. Fragm. Florist. Geobot. Ann. VI, Pars 3: 261-286.

Fijałkowski D. 1962. Wykaz rzadszych roślin Lubelszczyzny. Część V. / List of more rare species of the Lublin region. Part V. Fragm. Florist. Geobot. Ann. VIII, Pars 4: 443-468.

Fijałkowski D. 1963. Wykaz rzadszych roślin Lubelszczyzny. Cześś VI. / List of more rare species of the Lublin region. Part VI. Fragm. Florist. Geobot. Ann. IX, Pars 2: 219-237.

Fijałkowski D. 1964. Wykaz rzadszych roślin Lubelszczyzny. Część VII. / List of more rare species of the Lublin region. Part VII. Fragm. Floristi. Geobot. Ann. X, Pars 4: 453-471.

Fijałkowski D. 1971. Charakterystyka geobotaniczna kompleksu wodno-torfowiskowego koło Wytyczna w województwie lubelskim. / Geobotanical characteristics of an aquatic-bog complex near Wytyczno in Lubelskie Voivodship (region). Folia Soc. Sci. Lub. sect. B, 11: 3-10.

Fijałkowski D., Topolska G. 1981. Ciemiężyce (Veratrum L.) na Lubelszczyźnie. / Veratrum L. in the Lublin region. Folia Soc. Sci. Lub. 23 (1): 13-16.

Jasiewicz A. 1981. Wykaz gatunków rzadszych i zagrożonych flory polskiej. / List of more rare and endangered species of the Polish flora. Fragm. Florist. Geobot. Ann. XXVII, Pars 3: 401-414.

Jasnowska J., Jasnowski M. 1977. Zagrożone gatunki flory torfowisk. / Endangered species of bog flora. Chrońmy Przyrodę Ojczystą, 33 (4): 5-20.

Jasnowski M. 1972. Rozmiary i kierunki przekształceń szaty roślinnej torfowisk. / Dimensions and directions of transformations of the vegetation cover of peat bogs. Phytocoenosis, 1: 193-208.

Jaworowski P., Sobków C., Czarnecki A., Celmer T., Szablowski J. 1996. Melioracje wodne, ich wpływ na środowisko przyrodnicze i gospodarkę rolną. / Drainage and irrigation, their effects on the natural environment and water management. Wyd. Uniwersytetu Mikołaja Kopernika, Toruń, 14, 36-37, 64.

Kaźmierczakowa R., Zarzycki K. (red). 2001. Polska Czerwona Księga Roślin. Paprotniki i rośliny kwiatowe. / The Polish Red Book of Plants. Pteridophytes and flower plants. PAN, Instytut Botaniki im. W. Szafera, Instytut Ochrony Środowiska, Kraków.

The Convention on the Conservation of European Wildlife and Natural Habitats. Bern, 19 September 1979, European Treaty Series (ETS): 104.

Kucharczyk M., Wójciak J. 1995. Ginące i zagrożone gatunki roślin naczyniowych Wyżyny Lubelskiej, Roztocza, Wołynia Zachodniego i Polesia Lubelskiego. / Critically endangered and endangered vascular plant species of Wyżyna Lubelska, Roztocze, Wołyń Zachodni and Polesie Lubelskie. Ochrona Przyrody, 52: 33-46.

Ludera F. 1976. Ochrona roślin. O ciemiężycy zielonej Veratrum lobelianum w Polsce. / Conservation of plants. On Veratrum lobelianum in Poland. Chrońmy Przyrodę Ojczysta, 32 (6): 59-61.

Michalczyk Z., Chmiel S., Turczyński M. 2003. Stosunki wodne w obszarze funkcjonalnym Poleskiego Parku Narodowego. / Water relations within the functional area of the Polesie National Park. [In:] Radwan S. (red.). Przyrodnicze podstawy ochrony i odnowy ekosystemów wodno-torfowiskowych w obszarze funkcjonalnym Poleskiego Parku Narodowego na tle antropogenicznych 
przekształceń środowiska przyrodniczego. / The environmental basis for the conservation and restoration of aquatic-bog ecosystems within the functional area of the Polesie National Park against the background of anthropogenic transformations of the natural environment. Acta Agrophys., 91: 26-43.

Mirek Z., Piękoś-Mirkowa H., Zając A., Zając M. 2002. Flowering plants and pteridophytes of Poland. A checklist. PAN, Instytut Botaniki im. W. Szafera, Instytut Ochrony Środowiska, Kraków.

The Regulation of the Minister of Environment of 16 May 2005 on types of natural habitatrs as well as plant and animal species requiring protection in the form of designation of Natura 2000 sites, Dz. U. (Journal of Laws) of 2005 no. 94 , item 795 .

The Regulation of the Minister of Environment of 9 July 2004 on protected wild plants. (Journal of Laws) of 2004 no. 168, item 1764.

Sołtys M., Różycki A. 1996. Rzadkie i zagrożone gatunki flory naczyniowej w Poleskim Parku Narodowym. / Rare and endangered vascular flora species in the Polesie National Park. [In:] Radwan S. (red.). Funkcjonowanie ekosystemów wodno-błotnych w obszarach chronionych Polesia. / The functioning of wetland ecosystems in protected areas of Polesie. Wyd. UMCS, Lublin: 89-93.

Tomiałojć L. 1995. Punkt widzenia ekologa na melioracje wodne w Polsce w świetle przewidywanych zmian w środowisku przyrodniczym. / The point of view of an ecologist on drainage and irrigation in Poland in the light of expected changes in the natural environment. [In:] Tomiałojć L. (red.). Ekologiczne aspekty melioracji wodnych. / Ecological aspects of drainage and irrigation. Instytut Ochrony Przyrody PAN, Kraków: 49-70.

Wysocki C., Sikorski P. 2002. Fitosocjologia stosowana. Wydawnictwo SGGW, Warszawa: 31.

Załuski T., Kamińska A. 1999. Rola rowów melioracyjnych jako refugiów flory torfowiskowej na przykładzie kompleksu łąk w Koszelewkach. / The role of drainage ditches as refuges for bog flora on the example of a meadow complex in Koszelewki. Folia Universitatis Agriculturae Stetinensis, Agricultura, 197 (75): 373-376.

Zarzycki K., Szeląg Z. 1992. Czerwona lista roślin naczyniowych zagrożonych w Polsce. / The red list of threatened vascular species in Poland. [In:] Zarzycki K., Wojewoda W., Heinrich Z. (red.), Lista roślin zagrożonych w Polsce. / List of threatened species in Poland. Instytut Botaniki im. W. Szafera, PAN Kraków: 87-98.
Zarzycki K., Trzcińska-Tacik H., Różański W., Szeląg Z., Wołek J., Korzeniak U. 2002. Ecological indicator values of vascular plants of Poland. Ekologiczne liczby wskaźnikowe roślin naczyniowych Polski. W. Szafer Institute of Botany, Polish Academy of Science, Kraków.

Krasnaâ kniga Respubliki Belru". 2006. www.redbookbel.net

Červona kniga Ukraïni, t. 2, Roslinnij svit. 1996. Kiïv. Ukraïns'ka enciklopediâ.www.redbook.iatp.org.ua

\section{Gatunki rzadkie i chronione w rowach melioracyjnych i w fitocenozach $\mathrm{z}$ nimi sąsiadujących na terenie Poleskiego Parku Narodowego}

\section{Streszczenie}

W pracy przedstawiono wyniki badań florystycznych prowadzonych w latach 2003-2005 na obszarze Poleskiego Parku Narodowego i jego otuliny. $\mathrm{Na}$ dwunastu 100-metrowych odcinkach rowów melioracyjnych oraz w fitocenozach sąsiadujących wykonano spisy florystyczne, na podstawie których dokonano analiz kameralnych flory. Celem badań było określenie udziału gatunków o szczególnych wartościach przyrodniczych w rowach melioracyjnych, z uwzględnieniem występowania taksonów prawnie chronionych, rzadkich i zagrożonych w skali regionu, Polski i Europy. Porównano także udział tych gatunków z bogactwem roślin ,szczególnej troski” notowanych $\mathrm{w}$ fitocenozach sąsiadujących $\mathrm{z}$ badanymi rowami. Na podstawie składu florystycznego przeanalizowano występowanie taksonów, których liczba stanowisk na tle flory Polski wykazuje tendencje spadkowe. Liczba gatunków roślin naczyniowych stwierdzona w rowach $\mathrm{i}$ ich sąsiedztwie była zbliżona, jednak niskie wartości współczynnika podobieństwa sugerują rozbieżności w składzie gatunkowym tych siedlisk, co wpływa na ich większą różnorodność gatunkową. Obecność w rowach melioracyjnych gatunków ,specjalnej troski" wskazuje, że są one siedliskami cennymi dla PPN. Stwarzają one nisze dla gatunków rzadkich, chronionych i zagrożonych. 